Swarthmore College

Works

\title{
Burning The Breadboard: A New Approach To "The Optimist's Daughter"
}

Peter Schmidt

Swarthmore College, pschmid1@swarthmore.edu

Follow this and additional works at: https://works.swarthmore.edu/fac-english-lit

Part of the English Language and Literature Commons

Let us know how access to these works benefits you

\section{Recommended Citation}

Peter Schmidt. (2019). "Burning The Breadboard: A New Approach To "The Optimist's Daughter"'". English Literature Faculty Works.

https://works.swarthmore.edu/fac-english-lit/348

This work is brought to you for free by Swarthmore College Libraries' Works. It has been accepted for inclusion in English Literature Faculty Works by an authorized administrator of Works. For more information, please contact myworks@swarthmore.edu. 


\title{
Burning the Breadboard: \\ A New Approach to The Optimist's Daughter
}

\author{
Peter Schmidt \\ Swarthmore College
}

In one of The Optimist's Daughter's most vivid scenes, when Laurel confronts Fay during the novel's climax, Laurel uses a wooden breadboard made by her dead husband to stand for all that she values and Fay trashes. Laurel even weaponizes Philip Hand's hand-made creation: "Laurel held the board tightly" as she threatens to smack Fay with it. "[F]or a moment it seemed to be what supported her, a raft in the waters, to keep her from slipping down deep, where the others had gone before her" (177). Defending her family against Fay's invasion, holding up a board that Fay has burnt, scarred, and ruined, Laurel boasts that it represents the "whole story, Fay. The whole solid past." To which Fay replies, "The past isn't a thing to me. I belong to the future, didn't you know that?" (OD 178-79).

Such a vision of the past as a solid, well-made life-raft to be remembered and defended against vandals is a frequent theme in Welty's final novel, voiced particularly by Laurel herself but also by her mother. It's fitted into the novel's structure as carefully as Philip joined the wood pieces to make the breadboard. In a different medium, but with similar loving and meticulous craftsmanship, Welty pinned together snippets of text when she revised and assembled her manuscripts: Phil "planed—fitted—glued— 
clamped-it's made on the true" (177). Remembering Phil, Laurel admits that she has taken their love (and all of their unrealized possibilities together) and by force of memory "sealed [it] away into its perfection," "undisturbed and undisturbing" (154), following her old urge for "self-protection" and thinking of love as "shelter" (OD 161). This paper takes several angles of approach towards more deeply understanding central tensions in The Optimist's Daughter. Goaded by Fay, the novel's heroine struggles between her need to control and defend a past she feels is under attack and her intimation that her family's life and values can't truly be honored by such methods. The narrator also tells us that Laurel seeks to be "pardoned and freed" (OD 179)—but why, and from what? Welty's text explicitly connects the possibility of pardon with Laurel forgiving her parents. How might we understand this tie between forgiving others and being pardoned oneself? Key tropes will figure centrally to my discussion, particularly references to burning and to binding versus releasing, both in Welty's last novel and in a 1950s short story, "The Burning," which offers a different take on shared themes of invasion, death, and release. In addition, Becky McKelva's impassioned recitation on her deathbed of Southey's poem "The Cataract of Lodore" inspired me to explore other writers in Laurel's mother's beloved McGuffey's Fifth Reader, which led me to Tennyson, to "Break Break Break" (also in that anthology), and to a poem that was not there, though it's one of Tennyson's most famous: "The Lady of Shalott." Researching responses to Tennyson's parable about a woman artist—a textile artist, like Laurel 
McKelva Hand-I discovered a fascinating painting interpreting Tennyson by the English Pre-Raphaelite figure William Holman Hunt. I reproduce and discuss that painting below, to make the case that references to women artists and mirrors in Hunt's painting and Tennyson's poem can be useful lenses for readers of Welty. These sources give us a new twist on the Perseus story of mirrors, Medusa, and mimesis that so fascinated the author of The Golden Apples.

Always alert to irony, the heroine of The Optimist's Daughter knows that believing the past is an object to be possessed damages the very values it seeks to defend. "Until she knew Phil, she had thought of love as shelter... He had showed her that this need not be so. Protection, like self-protection, fell away from her like all one garment, some anachronism foolishly saved from childhood" (161). Honoring Phil, including what he made, cannot be a matter of fetishizing fixity or eternal continuities; his was a spirit of adventurousness and daring, and Laurel at her best knows this. In Marion Montgomery's words, Laurel learns to honor not only Philip Hand's careful workmanship, but also his ability not to make a fetish of things, or to claim to possess them forever. They are "a proximate but not eternal end" (156).

Laurel's mother, Becky, also is sometimes misperceived by her daughter as someone who needs to be defended from Fay. Laurel remembers Becky as a figure not unlike herself in times of trouble, seeking stasis and shelter. Becky when dying 
demanded to return to and repeat her lost past—and then accused her husband and daughter both of cowardice (OD 148, 151). Upon publication of One Writer's Beginnings, we learned to our shock and heartbreak that Becky's fate is actually a relatively mild version of what Welty's own mother went through in her agonizingly slow death, with Eudora as primary care-giver. Chestina Welty also demanded to return to her Andrews family "home place" in the West Virginia mountains, and she required her childhood piano be reinstalled in the Jackson house and the old favorite songs be sung. It was a desperate (and entirely human) gamble to keep loss at bay. It's hard not to think of Jay Gatsby: "Can't repeat the past? Why of course you can!" Yet both Laurel and her creator, with their inveterate irony and truth-telling, well know that what's past is irrecoverable: "something as incapable of being kept as of being proved: the lastingness of memory, vigilance against harm, good hope, trust in one another," as Welty's narrator pessimistically puts it in The Optimist's Daughter (146). Despite the novel's essential optimism in the midst of tragedy, which I'll explore in a moment, I want to stress here its grim and even brutal portrait of the death of the mind before the body. Becky's agony and fear makes her become someone else, autocratic and then terrified. She deeply insults and wounds her daughter, then dies "without speaking a word, keeping everything to herself, in exile and humiliation" (151). Is there any sadder and more frightening vision of a loved one's end in literature? Tolstoy's Ivan llyich's transition from self-centeredness to generosity seems anodyne by comparison. 
If Laurel acknowledges how much her impulse to think of love as protection came from her parents, she also realizes, however, that Becky gave her a counter-legacy as well: how to be what she called daring and "venturesome" (OD 153), as when she struck out from West Virginia with a new husband to build a life in Mississippi. That very same word is attributed in One Writer's Beginnings to Chestina Welty's own description of her youthful actions: "I expect I was pretty venturesome" (OWB 54). Both Welty's fictional and real mothers also tried to warn their daughters about "vaunting" (39) in the face of life's dangers, especially for women. As Welty puts it in her memoir, Chestina "knew that independent spirit so well, it was what she so agonizingly tried to protect me from, in effect to warn me against. ...To grow up is to fight for it, to grow old is to lose it after having possessed it. For her, too, it was most deeply connected to the mountains" (OWB 60). ${ }^{1}$

Scenes in The Optimist's Daughter involving Becky McKelva's handwriting bring together most startlingly the novel's contrarian themes of yearning for continuity and protection versus striking out for change. Stored away in the family desk in Mt. Salus, "in her mother's strict, pointed hand," is a bread recipe and her mother's teacherscollege diagram of Milton's Universe, "pigeonholing them here as though she'd be likely to find them useful again" (152-53). It is these and many other possessions of her parents that Laurel in the midst of the night storm futilely hopes to protect or shelter from Fay, even though she knows that Fay would have no interest in such texts, much 
less be able to imagine the inner lives they represented. ("Anyone reduced to the need to write, Fay would think already beaten as a rival" [135].) Later, after sunrise and the storm's passing, Laurel resolves to burn her parents' and her grandmother's papers, including Milton's Universe. Yet note how-perhaps influenced by her cathartic vision of Phil's ghost-Laurel no longer sees love or memory as a duty to protect or seal away the past in its supposed perfection. Peering into the outdoor incinerator, Laurel saw the words "this morning?" with the uncompromising hook of her mother's question mark, on a little round scrap of paper that was slowly growing smaller in the smoke. She had a child's desire to reach for it, like a coin left lying in the street for any passer-by to find and legitimately keep—by then it was consumed. All Laurel would have wanted with her mother's "this morning?" would have been to make it over, give her a new one in its place. She stood humbly holding the blackened rake." (OD 169)

Here Laurel is not trying to repeat or save her mother's world and words, but to capture their spirit of daring by making it over, that is, making it new. She rejects as a childish desire trying to keep a token of the past as if it's a "coin" that will allow her to timetravel. Her method is not protection but erasure — burning her hand writing and freeing her mother's last-seen words from the specific meaning they once had to a new 
referent, a future "morning" that will honor her mother's memory in a new way. (For the theme of the cleansing erasure of the past, see also the narrator's phrase "without any $\left.\operatorname{sign}^{\prime \prime}[170].\right)^{2}$

Laurel's fight with Fay over the breadboard is still to come, but arguably it's the burning-of-the-papers scene's openness to the new, not just Laurel's memory of the child Wendell Chisholm, that allows her to let go of her temptation to fight Fay with the "whole solid past" as her weapon. Welty's narrator, channeling Laurel's thoughts, underlines this revelation of her new values: "Memory lived not in initial possession but in the freed hands, pardoned and freed, and in the heart that can empty but fill again" (179). This moment links to the novel's last sentence, when Laurel glimpses the schoolchildren's hands as she is leaving Mt. Salus, perhaps for good: "The last thing Laurel saw, before they whirled into speed, was the twinkling of their hands, the many small and unknown hands, wishing her goodbye" (180). Seeing those hands, Laurel feels pardoned and freed, though the interesting questions are, why? And from what? One of my paper's main claims is that Laurel is finally freed from a view that memory is possession. She's freed, too, from the guilt she felt from failing to protect her parents from harm-including the mother whose last words accused her of cowardice. Laurel doesn't literally destroy Philip's and her mother's breadboard, of courseit's Fay who does that. But Laurel can table her breadboard defense when she realizes that Phil and her mother live most fully in her memory as living presences, not dead 
icons of perfection. Phil ultimately lives for her not so much because of his carpentry skills, though she honors those, but via confluence, their shared memory of seeing two rivers (the Ohio and the Mississippi) joining, just as they two joined their lives and set out together into the future $(O D 159-60)$. In this unforgettable "confluence" passage in Optimist's Daughter, a "morning" reference also figures: that moment she and Phil shared together "was the whole morning world" (160). Although Laurel doesn't know it yet, that memory girds her for the moment later in Part Four, when she sees that very word "morning" in her mother's handwriting as she burns the family papers (169).

Welty's heroine's conception of a usable past thus envisions the past not as a fixed text sealed in perfection, but a script to be continually erased, rewritten, and revivified. Both her heroine's story arc and the linguistic texture of Welty's novel enact this truth. Although Fay prides herself on representing change and the "future," unlike her antagonist Fay actually cannot change. Fay rewrites the past too, but she's doomed to do so solely based on her own self-interest. She's so narcissistic she's impervious to others' inner lives and stories-and in Welty's world those are the forces that, if we can hear them, will open us to change. Fay's ultimately imprisoned; Laurel, freed.

Let's now consider briefly four pieces of under-discussed textual and visual evidence supporting a reading of The Optimist's Daughter as a text engaged, as Rebecca Mark has claimed, "in an intricate rewriting of dominant Western literary 
narratives" ("Wild Strawberries" 336). One such text is central to Welty's novel and a beloved poem of Laurel's mother: Robert Southey's "The Cataract of Lodore" (1820). Another is a poem of Tennyson's inspired in part by Southey, and a key example of British Romanticism's romance with Arthurian legends: Alfred Lord Tennyson's "The Lady of Shalott" (1833/rev. 1842). I will pair a reading of this poem with commentary on a powerful interpretation of Tennyson's work by the British painter William Holman Hunt and argue that both are revelatory. Could The Optimist's Daughter be as deeply engaged with Tennyson's and Hunt's "The Lady of Shalott" as with Southey's "Lodore"? My tentative hypothesis is, yes. A fourth comparison-point is an earlier story Welty wrote, "The Burning." Like Tennyson's poem, strangely enough, it also features a damaged mirror and motifs of women's imprisonment, hallucination, and escape, as well as references to fire.

Rebecca Mark rightly reads Becky McKelva's recitation of "Lodore" on her deathbed as a rebuke to her husband. Its celebration of the waterfall not only evokes endless energy but also Welty's celebration of the link between sexual passion and women's creative powers, including their powers of resistance, "confounding, astounding." One of the Judge's areas of expertise, we are reminded, was designing flood control systems for Mississippi. Laurel's father dies from complications caused by a form of incipient blindness (a cataract) that Mark notes signifies petrifaction rather than movement-the opposite meaning of the "Cataract of Lodore." The Optimist's 
Daughter highlights many different examples of Judge McKelva's general deafness and blindness when it comes to women's words and gestures and their manifold, flowing meanings ("Wild Strawberries" 338-39). His wife Becky accuses him of cowardice and lies (OD 148-49) and uses Southey's poem as a way of "smiting and fighting"—escaping her deathbed imprisonment to return "up home" to her beloved family's West Virginia mountain. With tragic irony, Welty's narration stresses how Laurel's mother as she dies sees herself on trial, with Southey's poem as the only legal brief in her defense: "the more she could call back [i.e., remember and recite aloud] of "The Cataract of Lodore" the better she could defend her case in some trial that seemed to be going on against her life" (OD 147). Becky foresees an interloper like Fay and what the narrator discreetly calls the Judge's "letting ... go" of his bond to wife and daughter in quest of some form of elusive manly power (OD 170). But Becky is as harsh with her daughter as she is with her husband. Insane with fear and dementia on her deathbed, she knows exactly how to wound her daughter grievously, and does so. Part of the central action of The Optimist's Daughter is Laurel discovering how she can understand and forgive. She does so via recapturing her mother's own creative energy, inspired in part by hearing once again, years later, her mother's voice reciting Southey's words.

Could another famous nineteenth-century poetic portrait of women's creative energy - Tennyson's "The Lady of Shalott" — provide keys to understanding Welty's portrait of Laurel and Becky? I'm not sure. But I offer this possibility for your 
consideration. "The Lady of Shalott" was not included in the McGuffey's Fifth Reader volume that Laurel's mother treasured (OD 146). Another Tennyson poem was, "Break Break Break." Along with Southey's, that poem too could have haunted Becky on her deathbed, especially the lines "But O for the touch of a vanish'd hand,/ And the sound of a voice that is still!" But "The Lady of Shalott" is arguably a poem of Tennyson's that most daringly explores feminist themes of imprisonment, resistance, representation, and women's creativity, as recent commentators have recognized (Poulson, Zanzucchi, Brownbridge).

Rewriting an Arthurian legend re-told in an Italian novel of the thirteenth century, Tennyson's Lady of Shalott is imprisoned in a tower, doomed by the threat of a curse forever to weave images on her loom taken from a mirror, never directly from the outside world. (The Lady sets up a large mirror reflecting images from outside her tower, of Camelot and those who pass on a nearby road; she never is able to leave her confinement.) Tennyson's poem makes it clear that for the Lady such an evasion of the curse was only partially successful: she sees her images as mere "shadows of the world," and says "I am half-sick of shadows" - yet "in her web she still delights/ To weave the mirror's magic sights." Lady Shalott's doom comes when she sees Lancelot riding by in the mirror-reflection and can't resist looking directly out the window at his "helmet and the helmet-feather/ Burn'd like one burning flame together,/ As he rode down to Camelot." In a reversal of the Perseus/Medusa story, in Tennyson it's the male gaze and 
presence, not Medusa's, that kills. The mirror cracks "from side to side," invoking the curse. The Lady of Shalott leaves the tower, boards a boat on which she writes her name, and then drifts down a river dying, until her beautiful corpse is at last found and wondered at by the knights and ladies of the Round Table.

It would be easy to read Tennyson's poem as cautionary and even anti-feminist. The Lady's entire world is undone by gazing on a living man, and she is fated to be admired only as a beautiful corpse. (Painted images of the dead or dying Lady of Shalott in her boat were frequently made by Pre-Raphaelite painters obsessed with Tennyson's poem, including Walter Crane and John William Waterhouse; they couldn't resist the pathos of her passivity.) From this point of view, it's the Lady's loss of her powers that's most affective part of her story; she's interesting and moving because she's beautiful and doomed. She may have impressive powers and ambition, but those powers are always limited, representing what Coleridge called Fancy rather than Imagination. Fancy imitates preexisting images and recombines them; it cannot invent. And in the Lady of Shalott's case, her images may seem to be magical, but they're really just reproductions of reproductions, shadows of shadows. It's thus no accident that she's imagined imprisoned in a tower room until her moment of crisis.

But some past and present interpreters have suggested that Tennyson's poem's tragic narrative resists any conclusion that women's creative powers must only be secondary, involving mere copying. In this reading, both the pathos and the importance 
of the Lady's story comes from her powers being imprisoned. The story finds fault not with her powers but with the social/cultural forces that are responsible for her captivity and doom. Rightly understood, the story's pathos is thus politicized.

William Holman Hunt's 1905 painting Lady of Shalott broke new ground in this regard. Hunt's Lady is a version of Penelope from Homer's Odyssey. She weaves and re-weaves images taken from the world in order to achieve power, gain a place in the world, and resist a curse - all of which Penelope does successfully, but the Lady of Shalott does not. We might even say that the Lady's use of the mirror as part of her artistry, as reimagined by Hunt, mimes Perseus'use of a mirror. For Perseus too used a mirror to evade a curse. For readers of Welty's The Golden Apples and One Writer's Beginnings, such a connection has special resonance, for they remember that Welty was drawn to the paradoxes of the Perseus story. She eloquently interpreted it as a parable of the artist at work (all artists, not just women artists). Any great story has an unspeakable truth at its heart that can only be seen and named indirectly; otherwise, evil's force may paralyze us. Stories are Persean mirrors. Just as importantly, Welty suggested that the true artist has to identify as deeply with Medusa-both her anger at imprisonment and the creative energy with which she resists and evades containmentas with Perseus. A strong artist's imagination must be androgynous and empathetic.

In Hunt's vision, the Lady of Shalott's tower room is loaded with images representing the entire Western artistic tradition, both its visual archive and its literary 
canon from Homer to the present. Hunt's catalog of images includes fragments of a scene of Mary worshipping the baby Jesus (to the left) and (to the right) a retelling of the Greek legend of the Golden Apples (!). Tennyson's poem gives no catalogue of the artist's possessions, other than mentioning the mirror and her "velvet bed." Nor does it contain a reference to the Golden Apples. That the Golden Apples legend features in Hunt's painting should not be a surprise, since the tale had recently been made even more popular by the publication of Yeats' "The Song of Wandering Aengus" (1899), with its memorable lines about lost love, wandering, and plucking "the golden apples of the sun/ the silver apples of the moon." Perhaps alluding to Yeats, Hunt's painting shows a crescent moon behind the tree-as well as Atlas $^{3}$ holding in one arm the skin of the defeated dragon who guarded the Hesperides garden, while his other arm reaches up to select an apple as three nymphs doze near his feet. Depictions of the Garden of the Hesperides and its dragon and nymphs were also popular among the Pre-Raphaelites, and Welty of course mentions loving "Wandering Aengus," her introduction to all of Yeats' work (OWB 81).

What's most startling about Hunt's interpretation of Tennyson's "Shalott" —and very relevant for readers of Welty-are 1) his painting's placement of the mirror and 2) Hunt's portrait of the Lady's weaving at the moment the curse takes effect.

Where is the mirror in Hunt's picture? It takes some study to figure it out: what at first looks like a window behind the Lady, opening out to a view of Lancelot and 
Camelot, suddenly reveals itself to be a mirror image. (See the Russian samovar in the painting's foreground and a portion of the tapestry reflected in the mirror-window space. The image of Lancelot on his horse brandishing his sword is a mirror-reflection too.) That means the actual window looking out into the "real" world is positioned precisely where we, the viewers of the painting, stand. It's "our" space and world that, along with Lancelot, activated the Lady's curse when she looked our way.

To depict the curse in action, Hunt shows the victim standing in her tower room suddenly assaulted by the threads of her tapestry-in-progress. Her gaze is not now fixed on the male heroes Lancelot or Atlas/Hercules/Perseus, but on her own work: she stands within the very frame of her half-finished tapestry laid out horizontally over the floor. Two birds fly in front of her; her hair coils and spikes upward; her skirt has become disheveled and twisted; and loose threads from the tapestry spiral around her, pinning her left arm awkwardly to her side and beginning the process of derangement and imprisonment that will lead to her death. Yet in the midst of this drama her face and downward gaze are curiously expressionless—which precisely captures the words about the Lady that Tennyson chose, "a steady stony glance" and "a glassy countenance," both evoking the Perseus/Medusa story. A reproduction of Hunt's Lady of Shalott is on the next page, but the threads whirling around and binding her may be hard to see. Look in particular for the awkward posture of the Lady's left arm and hand as they are bound to her side by the demonic threads: 


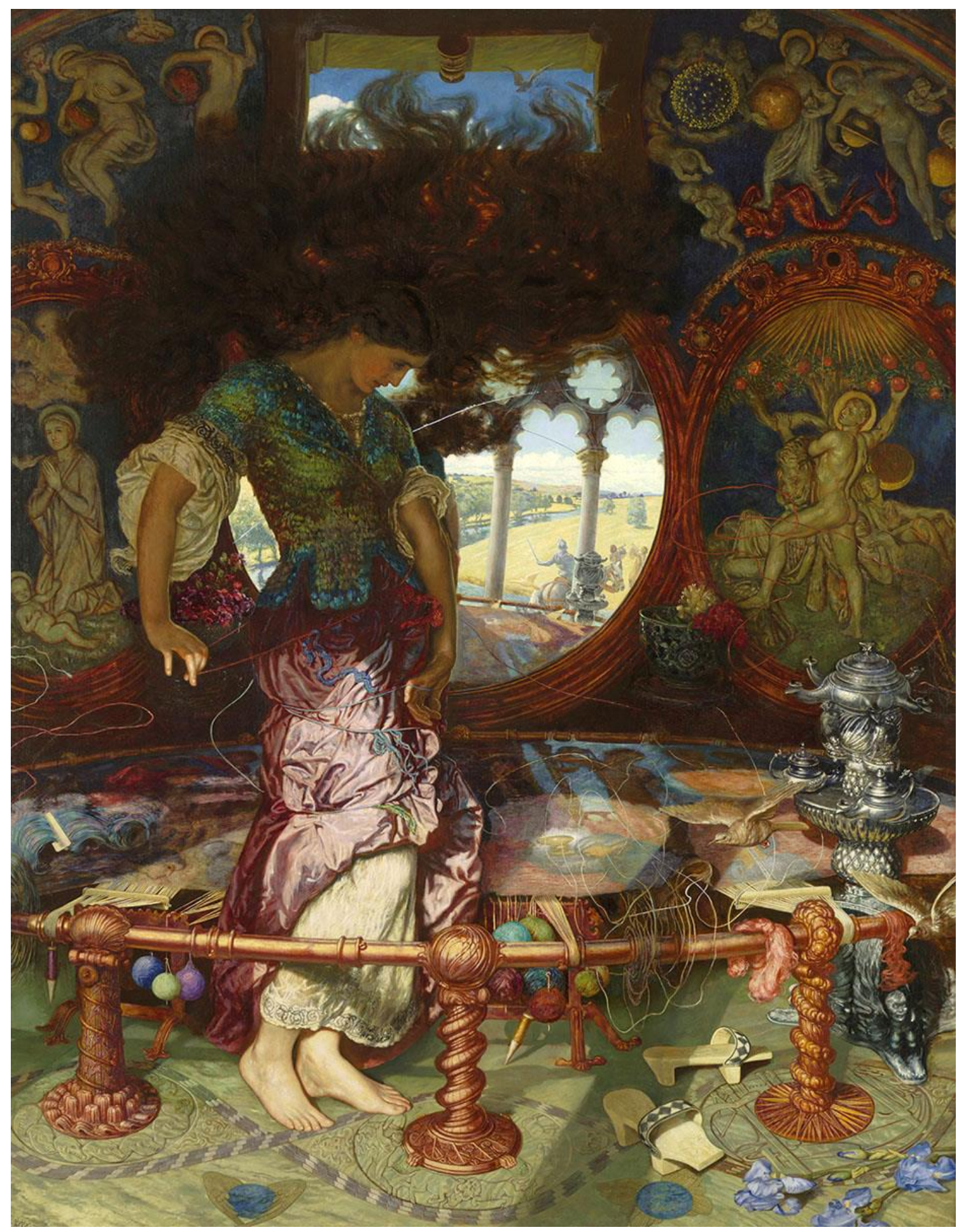

Image credit:

William Holman Hunt English, 1827-1910

The Lady of Shalott, c. 1888-1905

Oil on canvas, $741 / 8 \times 575 / 8 \mathrm{in}$. $(188.3 \times 146.4 \mathrm{~cm})$

Wadsworth Atheneum Museum of Art, Hartford, CT

The Ella Gallup Sumner and Mary Catlin Sumner Collection Fund, 1961.470 
Photography credit: Allen Phillips\Wadsworth Atheneum

When Tennyson saw an early version of the planned painting, he allegedly berated Hunt for misreading his poem ${ }^{4}$ — which, if true, was unfair, since Tennyson's poem explicitly says that when the Lady gazed on Lancelot "Out flew the web and floated wide."

I have no idea whether Welty knew of Hunt's painting and/or of the poem on which it was based. Someone will need to explore Welty's papers in the archives, and her library in her former home in Jackson. But I'd also wager that readers of The Optimist's Daughter don't need proof that Welty knew poem and painting to see their eerie connections to Laurel McKelva Hand and her drama. ${ }^{5}$ Laurel is a textile designer back in Chicago, working with fabrics of all kinds, including theater curtains and tapestries. She's not imprisoned in a tower but feels cursed in other ways, and at the height of her crisis during a midnight storm she barricades herself in her parents' study. She repeatedly tries to protect the images of her parents that she's woven in her head from what she perceives to be Fay's violations, yet over much of the novel she finds the entire world she constructed in her imagination unraveling. Even more strangely, her sanctum too is invaded by a bird-a harbinger of death that's in Hunt's painting but not Tennyson's poem. As numerous commentators have stressed, though, without Fay's incursion into Laurel's and her parents' safe spaces, Laurel would have remained bound within her own web of overly simplified narratives about them. It takes Fay martial 
aggressiveness painfully to awaken in Laurel a truer, deeper, and more tragic understanding of her parents' legacy to her. Laurel finally is able to achieve catharsis, grieving both for her parents' losses and for her own. The text we read is Welty's web of the inner workings and reworkings of Laurel's memory, her internal drama and her reckoning with the past. And of course in the end The Optimist's Daughter is the story of achieved sanity, knowledge, forgiveness. Our Lady of Chicago is liberated, "pardoned and freed," and—unlike in Hunt's painting—Welty stresses that her heroine finally now has "freed hands" (OD 179; my italics).

In Tennyson's poem, the power of fire is entirely associated with Lancelot, from his war-horse's "burnish'd hooves," to his phallic sword, to his helmet and helmetfeather, which "Burn'd like one burning flame together" in the sun. In The Optimist's Daughter the power of burning is all Laurel's. But hers is the power of weaving as well, and Welty's text gives a rather different reading of mimesis and women's art than does Tennyson. Tennyson's and Hunt's Lady are undone when they see the real world, rather than shadows of it. But in Hunt's interpretation, especially, we are forced to ask why the Lady is so cursed, and what is lost by the loss of her artistry. Welty definitively flips the Shalott parable's sexual politics by having Laurel move from shadows to light, protective simplification to revelatory revision and new, deeper understanding. And the whole she's-undone-by-a-real-man plotline is, shall we say, discarded by The Optimist's Daughter onto the ash-heap of history. Or at least brilliantly parodied, via the novel's 
portrait of a "heroic" male's increasing blindness, and by its portrait of Fay, who in the end doesn't know how to fight and doesn't understand how and why her "victory" is a defeat.

"[Laurel] stood humbly holding the blackened rake" (OD 169). Speaking of victory by fire, we might briefly consider for comparison's sake an earlier story of Welty's that has a similarly incendiary understanding of how the past must be undone and even burnt—or at least profoundly re-woven—in order to imagine for ourselves a different future. That text is Welty's only story about the Civil War, "The Burning," published not quite two decades before The Optimist's Daughter. My colleague Alex Werrell's essay for this volume will go more deeply into the figurations of memory, mirrors, and historical change in this tale, but let me draw to a close with a few points about placing in conversation those two very different Welty texts.

Mirrors are emblems of mimesis, but arguably all the many mirrors that appear in Welty's writing (think of "Clytie" and "Petrified Man" for starters) reveal that Welty has a strange conception of mimesis indeed. She conceives of her art as something very different from providing a strictly realistic representation of people and things as they "are," sealed in their identities with fixed social positions and meanings. Mirrors embedded in Welty's fiction enact metamorphosis, they overflow with motion and metaphors; they highlight blockage and imprisonment and its undoing; and they depict 
the causes of individual and social change. In short, her mirrors intervene in and produce "the real"; they don't just reflect it. And perhaps never more so than in the climactic scene in "The Burning," when the slave Delilah comes across a huge Venetian mirror lying in the cinders of the hearth of Rose Hill after it has been invaded and burnt by Union soldiers, and after the mansion's mistresses, Miss Myra and Miss Theo, have used their slave woman one last time, to help them hang themselves.

The mirror's frame has two carved slaves that appear to be propping up an image surface solely meant for whites' self-regard. (Delilah imagines those black slaves "looking almost into the glass themselves, as if to look back through a door" [CS 492; my emphasis].) Now freed by the war's chaos, Delilah walks through that door; she gazes into the mirror. What she sees is an apocalyptic vision of past, present, and future wars roiling like a flood as one world is swept to self-destruction while another emerges in the aftermath. Some of those images, even more strangely, seem to echo Hunt's painting, particularly the flying birds that appear before the Lady, and the terror of her hallucination and vertigo.

The page in "The Burning" rendering Delilah-in-the-mirror being attacked by winged creatures and other visions is perhaps more baroque and darkly cryptic than any other Welty wrote (CS 493). It's somewhat reminiscent of another famous image, Goya's etching The Sleep of Reason Produces Monsters. ${ }^{6}$ Welty's words for this moment are: "all this world that was flying, striking, stricken, falling, gilded or blackened, mortally 
splitting and falling apart, proud turbans unwinding...." Unlike Margaret Mitchell's representation of the burning of the Confederacy, Welty's mirror presents what is seen through an ex-slave's eyes. What she encounters stuns her. Delilah sees her dead son Jonah's image rise to the surface, her boy known to the whites as Phinny. Suddenly, confusing dialogue between Miss Myra and Miss Theo earlier in the story makes horrific sense. Miss Myra insisted that Phinny was her child, born of an affair with a Confederate officer. Her sister Theo ${ }^{7}$ stoutly contradicts her: "Phinny" was black, not white, fathered by their brother Benton when he raped Delilah. At their father's urging, the child was confined to Rose Hill's upper floor and has just burnt to death (488-89). At least, that's the most plausible possibility among the swirl of plot-lines the story releases. One fact is certain, but we don't learn it until the mirror scene five pages later (488 vs. 493):

Delilah loved her child and knew him by a different name, Jonah, signifying how he had been swallowed by the vices of slavery (493).

In short, Welty's representational mirror-text "The Burning" presents not "the whole solid past" but a collective Southern memory full of lies or half-truths covering trauma and its consequences. Those cursed narratives have to be "unwound" and then burnt so that other stories—such as Delilah's—can emerge. Delilah gathers Jonah's (Phinny's) bones from the ashes, looks in the mirror again, steps out of the ruined house, removes jewelry and shoes from her dead mistresses, and marches toward the Big Black River with her newly claimed possessions folded into the "manifold fullness" of 
her skirts or woven into her turban, the headgear topped by a Jubilee cup as she begins her own Jubilee exodus from slavery and Rose Hill's burnt hulk (493-94). ${ }^{8}$

"The Burning"'s ending is disturbingly ambiguous. Will Delilah drown in the Big Black, weighed down by all her loot; or is she marching toward a new, emancipated life? Delilah herself is sure the river won't rise until after she's crossed it. To me, her confident carriage's steady progress is directly reminiscent of the unstoppable Phoenix Jackson from "A Worn Path." Delilah has "her own black locust stick" (494) to ward off snakes, while Phoenix used an umbrella-stick. What we can say for sure is this: Welty's mirrors and mimesis are sibylline; they reflect a liquid, not an immutable, past. They stir it up and change it—and the future too. Myra and Theo, so to speak, are cursed to suffer the Lady of Shalott's fate, their story-tapestries and sanity undone by an armored man on a horse invading their sanctum. But what will be released if a reader/viewer of Welty's parable can be as strong and heroic as Delilah is, as Phoenix was? Remember that "The Burning" was published in 1955, one year after Brown v. Board of Education and the rise of the revived Civil Rights movement. We can perhaps think of Welty's "The Burning" as a mirror held up to the modern U.S. once again in crisis and on fire (or about to be). It's not just a reflection of 1865 .

Less epic—but no less significant—Laurel's burning of the past is similarly empowering. What she leaves with is in her, not external to her, and reviving the past's presence within her paradoxically releases her from its spell. More than a few of Welty's 
protagonists, including many notable women, have superpowers that we scholars in Southern Studies would do well to channel. We need to drink and be in the cups of our own Jubilee or Juneteenth. As Welty notes in her stirring conclusion to One Writer's Beginnings, quoting from and commenting on the "confluence" passage from her farewell novel, human memory is not static; it's not simply accessing stored data. Memories change when we summon them up, and their reactivation changes us, remixes us. Welty uses a "transit" analogy (OWB 104), implying motion, but even though the "confluence" scene in The Optimist's Daughterinvolves the train on which her heroine and husband are journeying, Welty's commentary on this scene (and the novel's structure itself) demonstrates that for her memory travels not in a railroadstraight line but via "spiraling" (OWB 102). The message given to us by Eudora Welty's Phoenix, Virgie, ${ }^{9}$ Circe, Delilah, Laurel, and others imparts the same wisdom. Welty's heroines are all in various ways sibylline; they partake of Penelope, Perseus, and Medusa. And, I would argue, they may draw on Tennyson's and Hunt's Lady of Shalott too, but with a different ending imagined for the heroine's story. To use the narrator's phrase, our task is to know the past deeply and then to "make it over" (OD 169) with the manifold fullness of fresh perspectives and voices on the march, old stories now understood differently and rewoven, no more madwomen in attics or towers, no more children imprisoned in Gothic mansions or internment camps, but more heads newly 
bedizened with turbans, with many roads and rivers to cross on a journey to a better country, a more perfect union.

\section{Works Cited}

Brinkmeyer, Robert. "New Orleans, Mardi Gras, and Eudora Welty's The Optimist's Daughter." Mississippi Quarterly 44 (Fall 1991): 429-41. Print.

Brownbridge, Joshua. "Does the Lady of Shalott Serve as Tennyson's Argument Against Established Gender Roles?" 2016. Web. Accessed 17 June 2019. https://docs.google.com/document/d/1Mtibor9CAjsgLOL3oydvkuoUIPsTjYI5Ndk $\underline{\text { UM46DYbE/pub }}$

Cole, Susan Letzler. Serious Daring: The Fiction and Photography of Eudora Welty and Rosamond Purcell. Fayetteville: U of Arkansas P, 2016. Print.

Enroth, C.A., General Editor. Major British Authors. New York, Toronto: Holt, Rinehardt and Winston, 1969. Print.

Hinton, Jane. "'Good as Gold': The Role of the Optimist in Three Novels of Eudora Welty." Jan Nordby Gretlund and Karl-Heinz Westarp, eds. The Late Novels of Eudora Welty. Columbia, S.C.: U of South Carolina P, 1998. 18-26. Print. Hunt, William Holman. Pre-Raphaelitism and the Pre-Raphaelite Brotherhood. Two volumes. New York: Macmillan, 1906. Print. 
Gretlund, Jan Nordby, and Karl-Heinz Westarp, eds. The Late Novels of Eudora Welty. Columbia, S.C.: U of South Carolina P, 1998. Print.

Gretlund, Jan Nordby. "Component Parts: The Novelist as Autobiographer." Jan Nordby Gretlund and Karl-Heinz Westarp, eds. The Late Novels of Eudora Welty. Columbia, S.C.: U of South Carolina P, 1998. 163-75. Print.

Kreyling, Michael. "Eudora Welty as Novelist: A Historical Approach." Jan Nordby Gretlund and Karl-Heinz Westarp, eds. The Late Novels of Eudora Welty. Columbia, S.C.: U of South Carolina P, 1998. 3-17. Print.

Manning, Carol S. With Ears Opening Like Morning Glories: Eudora Welty and the Love of Story-Telling. Westport, Conn.: Greenwood P, 1985. Print.

Mark, Rebecca. The Dragon's Blood: Feminist Intertextuality in Eudora Welty's The Golden Apples. Jackson: U P of Mississippi, 1994. Print.

Mark, Rebecca. "Wild Strawberries, Cataracts, and Climbing Roses: Clitoral and Seminal Imagery in The Optimist's Daughter." The Mississippi Quarterly 56.2 (Spring 2003): 331-50. Print.

Marrs, Suzanne. Eudora Welty: A Biography. Orlando: Harcourt, 2005. Print.

Marrs, Suzanne. One Writer's Imagination: The Fiction of Eudora Welty. Baton Rouge: LSU P, 2002. Print.

McHaney, Pearl A. "Eudora Welty: American Artist Abroad and 'The Burning.'" The Mississippi Quarterly 64.3 (2011): 503-523. Print. 
Montgomery, Marion. "The Swift Bird of Memory, The Breadboard as Art: Reflections on Eudora Welty and Her Story-Telling." Jan Nordby Gretlund and Karl-Heinz Westarp, eds. The Late Novels of Eudora Welty. Columbia, S.C.: U of South Carolina P, 1998. 145-60. Print.

Mortimer, Gail. Daughter of the Swan: Love and Knowledge in Eudora Welty's Fiction. Athens: U of Georgia P, 1994. Print.

Pollack, Harriet. Eudora Welty's Fiction and Photography: The Body of the Other Woman. Athens: U of Georgia P, 2016. Print.

Poulson, Christine. "Death and the Maiden: The Lady of Shalott and the PreRaphaelites." Re-framing the Pre-Raphaelites: Historical and Theoretical Essays. Ed. Ellen Harding. Aldershot: Scolar Press, 1996. 173-194. Print.

Prenshaw, Peggy Whitman. "The Construction of Confluence: The Female South and Eudora Welty's Art." Gretlund, Jan Nordby and Karl-Heinz Westarp, eds. The Late Novels of Eudora Welty. Columbia, S.C.: U of South Carolina P, 1998. 176-94. Print.

Runyon, Randolph Paul. "Not All That Separate: Welty and Warren, Medusa and Perseus." Eudora Welty Review 4.1 (2012): 135-151. Print.

Schmidt, Peter. "On Optimists's Sons and Daughters: Eudora Welty's The Optimist's Daughter and Peter Taylor's A Summons to Memphis." Mississippi Quarterly 50.4 (Fall 1997): 689-714. Print. 
Skei, Hans H. "The Last Rose of Mount Salus: A Study of Narrative Strategies in The Optimist's Daughter." Jan Nordby Gretlund and Karl-Heinz Westarp, eds. The Late Novels of Eudora Welty. Columbia, S.C.: U of South Carolina P, 1998. 12233. Print.

Tennyson, Alfred Lord. "The Lady of Shalott." [Two versions: 1832 and 1842.] Web. Accessed 17 June 2019. https://www.poetryfoundation.org/poems/45359/thelady-of-shalott-1832. https://www.poetryfoundation.org/poems/45360/the-ladyof-shalott-1842.

Vande Kieft, Ruth M. Eudora Welty. Revised Edition. Boston: Twayne P, 1987. Print. Welty, Eudora. The Optimist's Daughter. New York: Random House, 1972. Print. Welty, Eudora. The Collected Stories of Eudora Welty. New York: Harcourt Brace Jovanovich, 1980. Print.

Welty, Eudora. One Writer's Beginnings. Cambridge: Harvard UP, 1984. Print. Weston, Ruth D. Gothic Traditions and Narrative Techniques in the Fiction of Eudora Welty. Baton Rouge: LSU P, 1994. Print.

Wikipedia. "The Lady of Shalott" [by Alfred Lord Tennyson]. [Includes illustrations of several of the paintings cited in this essay.] Web. Accessed 17 June 2019. https://en.wikipedia.org/wiki/The Lady of Shalott

Wimsatt, Mary Ann. "Region, Time, and Memory: The Optimist's Daughter as Southern Renascence Fiction." Jan Nordby Gretlund and Karl-Heinz Westarp, eds. The Late 
Novels of Eudora Welty. Columbia, S.C.: U of South Carolina P, 1998. 134-44.

Print.

Wolff, Sally. A Dark Rose: Love in Eudora Welty's Stories and Novels. Baton Rouge: LSU P, 2015. Print.

Wolff, Sally. "Eudora Welty's Autobiographical Duet." J. Bill Berry, ed. Located Lives: Place and Idea in Southern Autobiography. Athens: U of Georgia P, 1990. Print. Yaeger, Patricia S. "The Case of the Dangling Signifier: Phallic Imagery in Eudora Welty's 'Moon Lake.'" Twentieth Century Literature 28.4 (1982): 431-52. Print.

Zanzucchi, Anne. "Alfred Lord Tennyson." The Camelot Project. University of Rochester. Web. Accessed 17 June 2019. https://d.lib.rochester.edu/camelot/creator/alfredtennyson\#

\section{End Notes}

1 For influential explorations of the ways in which Welty's The Optimist's Daughter and her memoir One Writer's Beginnings blur the boundary between life and art, memoir and fiction, see Wolff, "Autobiographical Duet"; Gretlund; Kreyling; Marrs's biography (particularly chapter seven, on The Optimist's Daughter, and chapter nine, on One Writer's Beginnings and Welty's "self-portraits" 1980-84); and Prenshaw. Especially 
pertinent for my paper is this insight from Marrs' biography: The Optimist's Daughter "drew upon the helplessness Eudora herself felt when, despite the ability to recognize and consider her mother's desperation, she was unable to assuage it. To speak her feelings of guilt, to recognize the impossibility of countering her mother's despair, to forgive herself for embracing the freedom that resulted from Chestina's death-all made [the novel] a source of release and renewal for Eudora" (332). For a succinct discussion of the changes Welty made in the manuscript between the version published in The New Yorker and the 1972 novel, see Marrs, Imagination 227-53. Many other Welty critics have explored the extensive interconnections between the two texts and the facts we know about the author's life, including the ways in which Welty's memoir uses fictional techniques and a writer's imagination to recreate and reimagine her parents' lives.

2 In this scene from Optimist's Daughter, it's not clear what piece of Becky's writing "this morning?" is from. The papers Laurel burns include her mother's old household accounts, her recipes and gardening diaries, her Teachers College notebook containing her sketch of Milton's Universe, and Becky's mother's letters to her. As Rebecca Mark has noted ("Wild Strawberries" 340), Laurel's father upon marrying Fay threw away "Laurel's mother's letters, the written word of women." "This morning?"—which the narrator pointedly notes is in Becky's handwriting, with the "uncompromising hook of 
her mother's question mark" (OD 169)—thus stands in for all of Becky's writing, her venturesomeness, daring, energy, and resistance (that uncompromising question mark...). For more on the significance of Laurel's absoption of her mother's "voice" even as she burns its physical representation, see later in my essay, as well as Mark's essay. Contrast this motif with its opposite, Laurel's tendency sometimes to withdraw into silence and sorrow, or to be silenced or ignored by others: see, for instance, Mortimer 161-65, who also stresses the importance of mythic avatars such as Daphne and Philomena.

Laurel enacts a similarly powerful erasure-plus-re-visioning of her mother's story of being abandoned in Baltimore with her father's (Laurel's grandfather's) body. Using indirect narration capturing Laurel's unspoken thoughts, the narrator shows Laurel in meditation quietly changing the meaning of "Baltimore" in her mother's story from literal to metaphorical: "Baltimore was as far a place as you could go with those you loved, and it was where they left you," Laurel says to herself (OD 151). For a fine reading of how Laurel's guilt first tried to sanitize and contain her mother's presence, but then discovers a new way to understand and channel her mother's powerful sexual/creative powers, see Mark, including this passage: "by the end of the night in the sewing room, Laurel has saved her mother's life. By being willing to spend a night of stitching together forgotten voices ... Laurel is saving her mother's voice" (346). Mark's "Wild Strawberries" is the best reading of the imagery associated with Becky's character in The 
Optimist's Daughter and, more broadly, it eloquently models how to write about the representation of sexuality and creativity throughout Welty's fiction. Mark's stress on Welty's "intertextuality" and polyvocality in Dragon's Blood has also been inspirational for my own essay—as has Yaeger's essay on "Moon Lake" and Pollack's work (especially her The Body of the Other Woman). We also all must celebrate Peggy Prenshaw's wry comment on "Welty's equanimity, even delight, in the presence of an unstable signifier" (189).

Contrast this motif of vocality with its opposite, Laurel's tendency sometimes to withdraw into silence and sorrow, or to be silenced or ignored by others. See, for instance, Mortimer 161-65, who stresses the importance of mythic avatars such as Daphne and Philomena.

3 Atlas went to the Garden of the Hesperides instead of Hercules, following Prometheus' advice: http://www.perseus.tufts.edu/Herakles/apples.html

4 According to the Wadsworth Atheneum, the official listed dates for the composition of Hunt's Lady of Shalott are 1888-1905, meaning that Hunt began working on it in 1888. Tennyson died in 1892. The story of Tennyson's disapproval of Hunt's image is mentioned on the Wikipedia page on "The Lady of Shalott," but no proper documentation is given. 
5 Hunt's Lady of Shalott painting was bought by the Wadsworth Atheneum in Hartford, Connecticut, in 1961, and displayed thereafter. For its provenance, see http://argus.wadsworthatheneum.org/Wadsworth Atheneum ArgusNet/Portal/public.as px?lang=en-US. Suzanne Marrs has created a calendar-database based on information in Welty's letters. It tells us that Welty visited Hartford, Connecticut, in 1975 (letter to Kenneth Millar), but not much more than that. It's not clear Welty visited the Wadsworth Atheneum during that 1975 visit. (And, in any case, that's beyond the date of publication for both "The Burning" and Optimist's Daughter.) Welty may have known Tennyson's poem (which is among his most famous) and/or seen Hunt's Lady of Shalott in reproduction, however. Regarding the painting, with the assistance of Atheneum staff members Allen Phillips and Edward G. Russo I can say that Hunt's Lady of Shalott was reproduced as the frontispiece in Hunt's two-volume compendium on the PreRaphaelite Brotherhood (1906); and in color in Enroth's Major British Authors anthology (1969), p. 562. I will be happy to share the full list in the Atheneum records of references to/reproductions of Hunt's Lady of Shalott from 1962 to 1971, but none of the other references found seem to me that promising as something Welty might plausibly have seen. Thanks to Suzanne Marrs, Harriet Pollack for assistance with this research, as well as to the Atheneum staff-none of whom are culpable for any mistaken assumptions I may have made. For one extensive discussion of threads and textile analogies to writing 
in The Optimist's Daughter, see Mortimer 145-46. Mortimer also insightfully maps bird references $(153-55 ; 160-65)$ and water/flood imagery (151-52). One indication that Tennyson's poem remains popular: in the 2019 Netflix series based on Armistead Maupin's Tales of the City novels, in the second episode Sam reads aloud part of "The Lady of Shalott" to Anna Madrigal. It's one of her favorite poems, and she knows both the original and revised versions.

6 For Goya's etching The Sleep of Reason and basic information, see https://en.wikipedia.org/wiki/The Sleep of Reason Produces Monsters

7 Miss Myra and Miss Theo in "The Burning" are one of many pairs of women featured in Welty's stories, where one is more conventionally "ladylike" and the other is what used to be called a tomboy (my students now use the phrase "gender fluid"). Consider "Beautiful Ohio," "Moon Lake," and "June Recital," to name just three. It's Myra who not only defends her family's lie about the child who suddenly appears in their midst, but also is convinced that it's hers and is white. Her sister Theo is sometimes portrayed as a rather tragicomically deluded aristocrat too, but she's the one to defy the family's lies about the child, and she's the one marked with Welty's favorite signs of androgyny. For fine readings of "The Burning" in its autobiographical and historical contexts, see McHaney; Cole 29-33; and also Alex Werrell's essay in this volume. Cole briefly mentions the relevance of Tennyson's "The Lady of Shalott" to Welty's "The Burning," 
but did not have room to explore the connection fully. Cole does mention Tennyson's poem to stress the contrast between Myra and Theo's limited modes of vision and understanding ("unable to survive without her magic mirror") versus Delilah's (32-33). For useful summaries of Welty's interest in the Perseus and Medusa story, including how she works with it in The Golden Apples and elsewhere, see recent publications by Cole and Runyon.

8 Although many now associate the Jubilee Cup with rugby, in the past Jubilee cups marked significant anniversaries in either private or collective histories. A "Jubilee" can also commemorate an emancipation or a new beginning. Etymologically jubilee is connected to key moments in Jewish history and memory and is derived from the Hebrew yōbhē/(ram's horn). A year of emancipation and restoration is mandated in ancient Hebrew law, to be held at least every 50 years (or more often) honoring the exodus of Jewish slaves from Egypt. The Merriam-Webster Dictionary stresses another meaning: a Jubilee is a "religious song of black Americans usually referring to a time of future happiness," not to mention the demise of slavery. https://www.merriam-webster.com/dictionary/jubilee [.] That is why Margaret Walker's 1966 novel answering Margaret Mitchell's Gone With The Wind with a black-centered vision of slavery, the War, and Reconstruction was entitled Jubilee. As Delilah in Welty's story tastes the flavors still lingering in her former mistress' Jubilee cup (CS 494), her 
addition of the trophy to her turban shifts the cup's meanings from the whites' to hers at the very moment when she begins her exodus from Rose Hill's ruins.

9 In One Writer's Beginnings, Welty notes that Virgie Rainey in The Golden Apples "might have always been my subject" (102). As I draw to a conclusion, I would like to mention here Suzanne Marrs' and Ruth Vande Kieft's work on Welty and The Optimist's Daughter as being particularly useful for my essay, as were Manning's, Mark's, Weston's, Brinkmeyer's, Wimsatt's, Mortimer's, and Hinton's readings of the revisionary optimism at the heart of Welty's final novel. (For a valuable contrarian reading of The Optimist's Daughter arguing it is deeply flawed and regressive, see Skei.) Manning, Vande Kieft, Marrs, Mortimer, and Hinton are among those who stress how Laurel first rebels against false or simplistic accounts of her father's life, which Welty links to the general staleness and provinciality of the status quo in Mt. Salus. Later, Lauren then heroically directs that same skeptical energy toward her own carefully curated narratives of her parents' past, a heroic form of identification with them that at least releases catharsis and allows Laurel to mourn. The paradoxical optimism of Welty's final published novel was something I first traced in an earlier essay comparing it to Peter Taylor's A Summons to Memphisalso featuring a protagonist uncovering complicated family history and the hidden lies told by the protagonist as well as others. 
An aside: Brinkmeyer, Weston, and Mark all call Fay's energy "fairy"-like. To me Fay seems more like a noisy bulldozer, though one with an unusual fondness for pink. Tennyson would have no trouble with applying the word "fairy" to a powerful female creator figure, however, for "The Lady of Shalott" explicitly says that the heroine has "fairy" powers. In contrast, Hunt's painting depicts the Lady of Shalott as anything but ethereal, nor is she at all like the "glimmering girl" in Yeats" fantasy.

An earlier version of this essay was given at the Eudora Welty Society conference at the College of Charleston, South Carolina, on February 21-23, 2019. Many thanks to Harriet Pollack and Julia Eichelberger, to the Welty Society and the conference Program Committee, to all those who attended, and to the College of Charleston for organizing such a substantive and celebratory conference. 